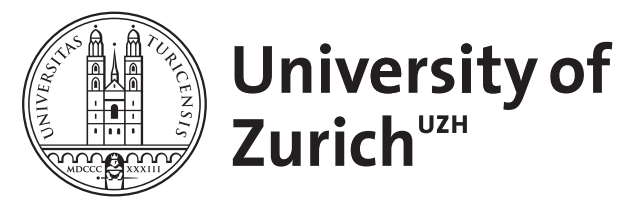

\title{
Cardiovascular determinants of life span
}

\author{
Shi, Y ; Camici, G G ; Lüscher, T F
}

\begin{abstract}
The prevalence of cardiovascular diseases rises with aging and is one of the main causes of mortality in western countries. In view of the progressively aging population, there is an urge for a better understanding of age-associated cardiovascular diseases and its underlying molecular mechanisms. The risk factors for cardiovascular diseases include unhealthy diet, diabetes, obesity, smoking, alcohol consumption, physical inactivity, and aging. Increased production of oxygen-derived free radicals plays an important role in mediating cardiovascular diseases. Oxidative stress affects the availability and/or balance of key-regulators of vascular homeostasis and favors the development of cardiovascular diseases. Reactive oxygen species are generated by different intracellular molecular pathways principally located in the cytoplasm and in the mitochondria. The mitochondrial protein p66Shc and the deacetylase enzyme SIRT1 were shown to be involved in different aspects of cardiovascular diseases. This review focuses on the latest scientific advances in understanding cardiovascular diseases associated to aging, as well as delineating the possible therapeutic implications of p66Shc and SIRT 1 in this process.
\end{abstract}

DOI: https://doi.org/10.1007/s00424-009-0727-2

Posted at the Zurich Open Repository and Archive, University of Zurich ZORA URL: https://doi.org/10.5167/uzh-29243

Journal Article

Published Version

Originally published at:

Shi, Y; Camici, G G; Lüscher, T F (2010). Cardiovascular determinants of life span. Pflügers Archiv: European Journal of Physiology (Pflugers Archiv), 459(2):315-324.

DOI: https://doi.org/10.1007/s00424-009-0727-2 


\title{
Cardiovascular determinants of life span
}

\author{
Yi Shi • Giovanni G. Camici • Thomas F. Lüscher
}

Received: 31 July 2009 / Accepted: 26 August 2009/Published online: 12 September 2009

(C) Springer-Verlag 2009

\begin{abstract}
The prevalence of cardiovascular diseases rises with aging and is one of the main causes of mortality in western countries. In view of the progressively aging population, there is an urge for a better understanding of age-associated cardiovascular diseases and its underlying molecular mechanisms. The risk factors for cardiovascular diseases include unhealthy diet, diabetes, obesity, smoking, alcohol consumption, physical inactivity, and aging. Increased production of oxygen-derived free radicals plays an important role in mediating cardiovascular diseases. Oxidative stress affects the availability and/or balance of key-regulators of vascular homeostasis and favors the development of cardiovascular diseases. Reactive oxygen species are generated by different intracellular molecular pathways principally located in the cytoplasm and in the mitochondria. The mitochondrial protein p66Shc and the deacetylase enzyme SIRT1 were shown to be involved in different aspects of cardiovascular diseases. This review focuses on the latest scientific advances in understanding cardiovascular diseases associated to aging, as well as delineating the possible therapeutic implications of p66Shc and SIRT 1 in this process.
\end{abstract}

Keywords Oxidative stress · Blood pressure - Obesity · Diabetes mellitus $\cdot$ Mitochondria

\footnotetext{
Y. Shi · G. G. Camici · T. F. Lüscher

Cardiovascular Research, Institute of Physiology, and Center Zürich, Switzerland

T. F. Lüscher $(\square)$

Department of Cardiology, Cardiovascular Center, University Hospital,

Ramistrasse, 100,

8091 Zürich, Switzerland

e-mail: karlue@usz.unizh.ch
} for Integrative Human Physiology (ZIHP), University of Zürich,

\section{Introduction}

To date, cardiovascular disease is the leading cause of death in western countries. Although the absolute incidence and mortality of cardiovascular disease are falling, figures are still very high. Thus, there is an urge for more efforts by the scientific community to identify new mediators and/or novel therapeutic targets for cardiovascular disease.

Cardiovascular disorders are a heterogeneous entity encompassing risk factors such as hypertension, diabetes, smoking, obesity, and aging, as well as true cardiac conditions such as coronary artery disease, infarction, and heart failure. However, certain traits seem to be a common denominator to different cardiovascular conditions. Usually, endothelial dysfunction is the earliest disturbance. However, it is rather difficult to be diagnosed before symptoms develop. The present nonexhaustive review discusses some of the latest scientific advances at the molecular level.

\section{Elevated oxidative stress and vascular dysfunction}

The endothelium, the innermost layer of the vascular wall, offers a primary protection against vascular dysfunction, occurrence of atherosclerosis, and thrombogenesis. Under physiological conditions, a balance between reactive oxygen species (ROS) damage and endothelial progenitor cellmediated repair keeps the integrity of endothelium and maintains endothelial functions [20]. However, under pathophysiological conditions, this balance shifts towards ROS-induced damage, which is due to additional cellular damage by protein oxidation and/or decreased endothelial progenitor cells' function [6, 32] (Fig. 1).

Nitric oxide (NO), the principle endothelial-derived relaxing factor [38, 107], possesses inhibitory effects on 
Aging and Cardiovascular Diseases

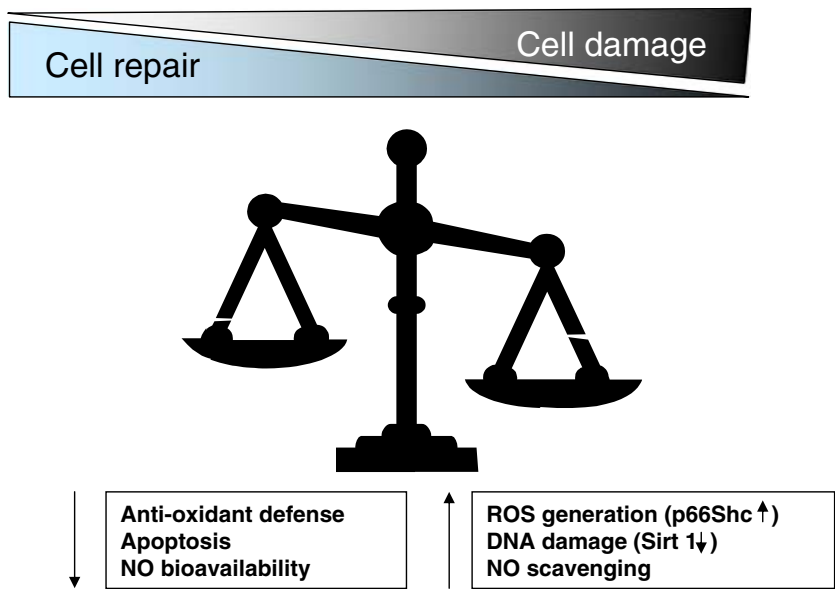

Fig. 1 With aging and cardiovascular diseases, the balance between noxious insults and protective systems is progressively lost favoring the development of endothelial dysfunction and vascular disease. $R O S$ reactive oxygen species, $N O$ nitric oxide

endothelium-derived contracting factors [38, 107]. When the release of $\mathrm{NO}$ is reduced and the production of endothelium-derived contracting factors is enhanced, endothelial dysfunction ensues [107]. In addition, NO plays a key role in preventing atherosclerosis by reducing the adhesion of platelets and leukocytes [8, 33] and by inhibiting the migration and proliferation of smooth muscle cells [69].

A large body of evidences reports a reduced blood flow in aged people or patients with hypertension, hypercholesterolemia, atherosclerosis, heart failure, or diabetes $[56,59$, 83]. This phenomenon is also observed in pertinent animal models and is associated with a reduced NO bioavailability and/or an enhanced endothelium-dependent vasoconstriction [7, 43, 91, 108]. These studies confirm endothelial dysfunction observed in cardiovascular disorders in human.

The elevated levels of superoxide anion $\left(\mathrm{O}_{2}{ }^{-}\right)$observed under disease conditions are a crucial factor for the loss of $\mathrm{NO}$ availability in endothelial cells since the expression of endothelial nitric oxide synthase (eNOS) in diseases is either declined [26] or preserved [92]. Superoxide anion inactivates $\mathrm{NO}$ in a few seconds resulting in the generation of another highly reactive species, peroxynitrite $\left(\mathrm{ONOO}^{-}\right)$. Peroxynitrite penetrates across the phospholipid membrane and produces substrate nitration, thereby, damaging DNA [98], modifying lipoproteins by oxidation [82], disrupting mitochondrial function [57, 58, 97], and depleting plasma antioxidants [106].

The increased production of ROS under disease conditions is also implicated in proinflammatory processes by directly acting as second messengers. For instance, ROS activate NF- $\mathrm{KB}$, a key transcription factor [27]. Activation of $\mathrm{NF}-\mathrm{KB}$, in turn, promotes the transcription of several critical genes for atherogenesis including cytokines such as tumor necrosis factor- $\alpha$ (TNF- $\alpha$ ), interleukin 6 (IL-6), monocyte chemoattractant protein-1 (MCP-1), and adhesion molecules (VCAM-1) [14, 28, 29, 39, 47, 50, 52]. Thus, oxidative stress is regarded as a key factor contributing to chronic inflammation [27].

\section{Oxidative stress in cardiovascular disease}

A large body of evidences underscores a critical role for oxygen free radicals in endothelial injury, aging, and cardiovascular diseases [17, 24, 31, 55, 107]. Aging shares several molecular features with cardiovascular diseases $[16,94]$. The free radical theory of aging is widely accepted as the reference concept describing the mechanism underlying aging and aging-related diseases [26, 35, 41, 42, 75, 84, 105]. Increased production of ROS in aging is associated with enhanced $\mathrm{ONOO}^{-}$formation [105], up-regulated expression of inducible nitric oxide synthase (iNOS) [26], NAD $(\mathrm{P}) \mathrm{H}$ oxidase [2], and/or a parallel down-regulation of antioxidants such as extracellular SOD [48] and decreased catalase activity [92].

The development of atherosclerosis is considered to be the result of chronic inflammation mostly induced by the increased production of ROS. The principal sources of free radical species in atherosclerosis are iNOS [30, 113], NAD (P)H oxidase [111], and/or cyclooxygenase-2 [5], since these proteins are expressed in atheromatous plaques. Importantly, ROS modify lipoproteins to the oxidized form, e.g., oxidized low-density lipoprotein (oxLDL), which has profound biological effects via the LOX-1 receptor in endothelial cells and the scavenger receptor- $\mathrm{A}$ in macrophages $[3,40,100,118]$. In addition to the decrease in eNOS activity [36, 89, 101], oxLDL increases the expression of VCAM-1 and MCP-1 protein through NF-kBmediated gene transcription $[3,22]$. This implies an intricate ROS-mediated inflammation in the occurrence of atherosclerosis.

Diabetes is a major risk factor for cardiovascular diseases [31]. The increased production of free radicals observed in diabetes results from reduced activity of superoxide dismutase $[19,22,89,96,101]$, reduced expression of heme oxygenase [19], as well as from enhanced expression of $\mathrm{NAD}(\mathrm{P}) \mathrm{H}$ oxidase $[62,69,112]$ and cyclooxygenase $[60,61,91]$. In addition, the unique glycation reaction in diabetes generates, yet, more oxidative free radicals through intermediate compounds that in turn increase the levels of reactive oxygen species [31, 45, 46, $87,88,95,103,119,121]$. Dicarbonyl compounds such as methyglyoxal and 3-deoxyglucosone and intermediate products of glycation are typical examples. The serum 
concentrations of both methyglyoxal and 3-deoxyglucosone are increased in patients with diabetes mellitus [99] indicating that free radicals play a crucial role in the pathogenesis of diabetes-associated complications [103, 114].

\section{The ROS sensitive protein p66She}

The mitochondrial adaptor protein p66Shc is regarded as an important mediator of aging since genetic deletion of p66Shc protein in the mouse causes lower levels of ROS and prolongs lifespan by 30\% [66]. The mammalian Shc locus encodes for three different ShcA adaptor proteins with respective molecular masses of 46, 52, and $66 \mathrm{kDa}$. The splice variant $\mathrm{p} 66 \mathrm{Shc}$ is the only isoform to participate in mitochondrial ROS generation and thus, to translate oxidative signals into apoptosis $[12,51,66,72]$. In fact, in the absence of p66Shc, mitochondrial oxidative phosphorylation is reduced in favor of glycolysis. In light of its pivotal role in ROS generation, many efforts have been made to investigate the pathophysiological relevance of p66Shc in ROS-mediated diseases [18, 23].

The expression pattern of p66Shc protein in humans was studied in young people, elderly, and centenarians. The expression of p66Shc in fibroblasts was shown to increase with age [79] suggesting that the expression of p66Shc protein concurs with the process of aging. In human peripheral blood monocytes, p66Shc messenger RNA expression is enhanced in diabetic patients compared to healthy subjects [78]. Given the up-regulated expression of p66Shc in aged people and in diabetic patients, the hypothesis that this mitochondrial adaptor protein p66Shc is linked to aging and/or ROS-related diseases is widely accepted. Genetically modified mice are a useful tool to study the role of p66Shc protein under pathophysiological conditions since identical She genomic organization, transcript assembly, as well as, a high degree of amino acid identity have been reported in mice and in humans [67].

In adipose cell culture experiments, insulin treatment increased the production of ROS in brown preadipocytes from wild type mice, but not in those from p66Shc knockout mice. Reintroduction of p66Shc expression ex vivo restored the insulin-stimulated ROS production in preadipocytes of p66Shc knockout mice, confirming that p66Shc plays a crucial role in ROS production [9]. Further, p66Shc knockout mice are resistant to high fat diet-induced obesity, which is shown as increased basal metabolism, reduced fat development, and increased insulin sensitivity of peripheral tissues [9]. These results imply that p66Shc is an important mediator of insulinsignaling pathway, as well as energetic metabolism.

In line with the above, a blunted age-dependent and NOmediated vasodilatation was maintained in the aorta of age- matched p66Shc knockout mice (Fig. 2) demonstrating that a preserved NO bioavailability in aged p66Shc knockout mice is due to lower aortic $\mathrm{O}_{2}^{-}$levels and reduced aortic 3-nitrotyrosine content [37]. Preserved NO availability in aged p66Shc knockout mice was shown to be dependent on a reduced ROS production and a consequently reduced scavenging [37].

The beneficial effects of p66Shc protein deletions are also observed in apoE knockout mice [18, 71]. High fat diet induces comparably high levels of serum lipid in both control and p66Shc knockout mice. However, the level of lipid peroxidation is lower in p66Shc knockout mice compared to control mice. This suggests a putative role of p66Shc in the oxidation modification of lipoprotein. Seemingly, p66Shc knockout mice are protected from high fat diet-induced aortic lesion due to a decreased oxidative stress and a decreased formation of foam cells [71]. These data indicate that p66Shc takes part in the development of ROS-mediated atherosclerotic lesion.
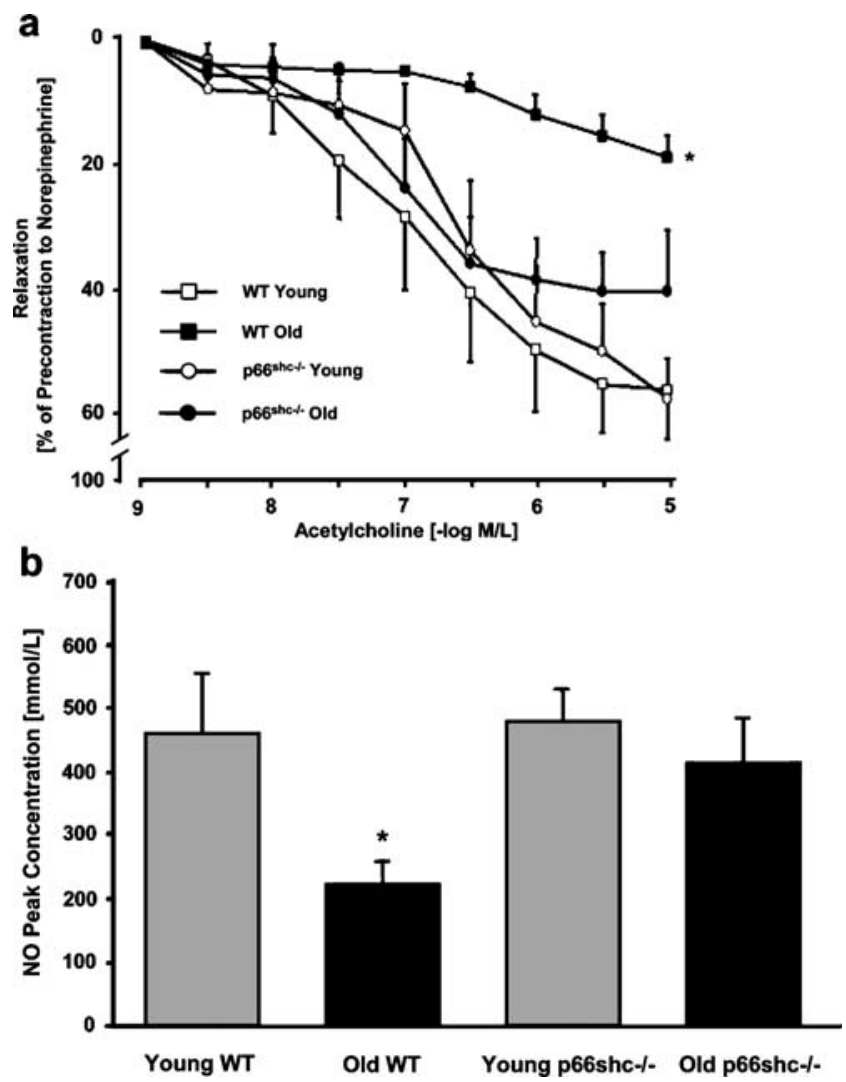

Fig. 2 a Age-induced changes in endothelium-dependent relaxation of WT and p66shc-/- aortas. Lines graph showing concentrationresponse curves to acetylcholine. Results are presented as mean \pm SEM; $n=7$ in each group. $M / L$ indicates $\mathrm{mol} / \mathrm{L}$. The symbol $\left(^{*}\right)$ indicates $p<0.05$ versus young WT. b Bar graph showing peak concentrations of NO in young (gray bars) and old (black bars) WT and p66shc-/- mice, respectively. Results are presented as mean \pm SEM; $n=4$ to 6 in each group. The symbol $(*)$ indicates $p<0.05$ versus young WT [84] 
In line with the observation that p66Shc expression is increased in diabetic patients [78], the expressions of p66Shc protein is enhanced in the aorta and the renal cortex of streptozotocin-induced type I diabetic mice [19, 64]. Glucose levels in serum were comparable in diabetic p66Shc knockout and wild type mice [19, 64, 65], indicating that the deletion of p66Shc protein does not affect the diabetic condition and the hyperglycemia. Nevertheless, p66Shc knockout mice are protected from diabetes-induced endothelial dysfunction [19] and diabetic glomerulopathy [65], which is due to reduced production of ROS and a decreased cellular apoptosis (Fig. 3). The above-described data underscore the pivotal role of p66Shc in diabetes-induced ROS production [19].

\section{The energy sensor-SIRT1}

SIRT1 belongs to histone deacetylase class III, which reverses protein acetylation and promotes DNA stability. SIRT1 also deacetylates a number of nonhistone target protein, including tumor suppressor p53 protein [54, 109], members of the Forkhead transcription factor family (FoxO) $[15,73,104,116]$, stress response protein ku70 and NF-KB [21, 117], and metabolic regulator PCG-1 $\alpha$ [86]. Owing to a unique nicotinamide adenine dinucleotide (NAD+)-dependent enzymatic activity, SIRT1 was recently considered as a promising therapeutic approach for aging and aging-associated cardiovascular diseases [93].

Starvation enhances the expression of SIRT1 protein in mouse liver and in human peripheral blood mononuclear cell, which returns to normal level upon feeding [73, 86]. The up-regulated SIRT1 protein deacetylates PGC-1 $\alpha$ in a $\mathrm{NAD}^{+}$-dependent manner in both hepatic cells and mice

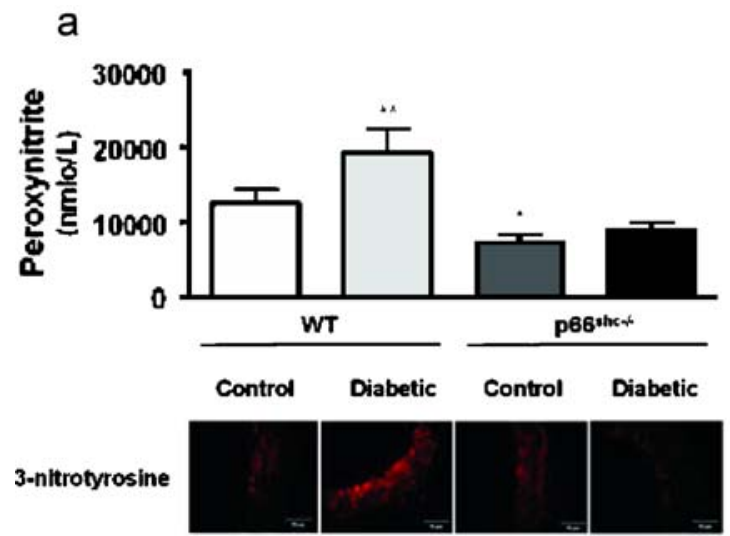

Fig. 3 a Bar graphs showing $\mathrm{ONOO}^{-}$levels determined by chemiluminescence. Results are presented as mean $\pm \mathrm{SEM} ; n=6$ in each group. $p<0.05$ versus control WT mice; $p<0.05$ versus control WT mice. Immunostaining of nitrotyrosine residues in aortas from control and diabetic WT and p66Shc-/- mice is shown. b Bar graphs livers, indicating a regulatory role of Sirt1 in the gluconeogenic/glycolytic pathway [86]. In a mouse model of chronic calorie restriction, which extends lifespan, the expression of SIRT1 protein is elevated in the calorie-restricted group [74]. Likewise, mice overexpressing SIRT1 share a similar phenotype to calorie-restricted mice, including lower body weight, lower cholesterol level, improved glucose homeostasis, and increased metabolic rate [13]. Thus, SIRT1 is an important mediator of the beneficial effects observed with calorie restriction and is probably involved in lifespan control.

The presence of SIRT1 protein was also observed in pancreatic $\beta$ cell [70]. In cell culture experiments, inhibition of SIRT1 reduced the secretion of insulin suggesting that SIRT1 is a possible target to insulin secretion [70]. In SIRT1 knockout mice, insulin levels are reduced in both normoglycemic and glucose tolerance experiments. Consistently, in a type II diabetic mouse, genetic up-regulation of SIRT1 [13, 76] or treated with resveratrol [68], a small molecule activator of SIRT1, enhances insulin secretion, and thus, improves glucose tolerance. These data underscore that the activator of SIRT1 is a potentially therapeutic principle for diabetes, especially for insulin-resistant type II diabetes.

SIRT1 also has beneficial effects on endothelial cells. In rat aorta, inhibition of SIRT1 ex vivo causes a blunted endothelium-dependent relaxation. Restoration of SIRT1 increases eNOS expression by deacetylation on both lysine 496 and 506 indicating that SIRT1 directly regulates eNOS [63]. In apoE knockout mice fed with high fat diet, the mouse overexpressing endothelial cell-specific SIRT1 maintains relaxation in the aorta accompanied by upregulated eNOS and a retarded atherogensis [122]. This result confirms a protective role of SIRT1 and eNOS for the

b

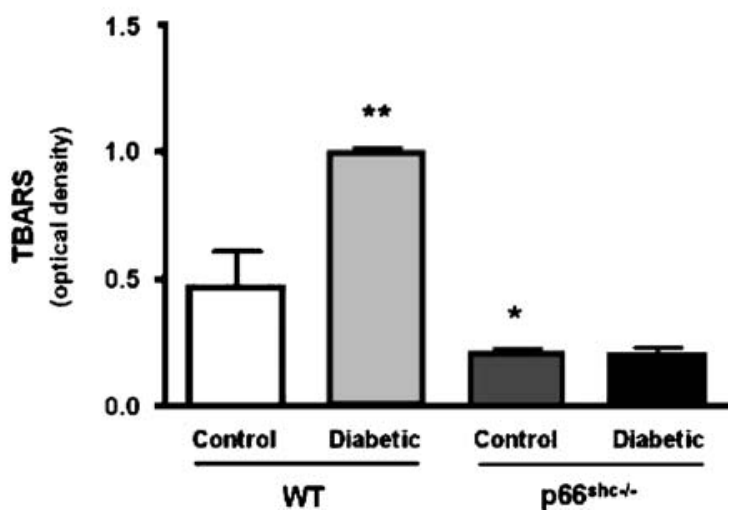

showing thiobarbituric acid-reactive substances levels in aortas from control and diabetic WT and p66Shc-/- mice. Results are presented as mean \pm SEM; $n=4$ in each group. The symbol $(*)$ indicates $p<0.05$ versus control WT mice; $p<0.05$ versus control WT [58] 
development of atherosclerosis. Nevertheless, NO donor increases SIRT1 expression and delays cell senescence in human endothelial cells [77]. Calorie restriction fails to enhance SIRT1 expression in eNOS knockout mice [74], suggesting that NO may also directly modulate SIRT1 expression.

In the aorta of streptozotocin-induced diabetic mouse, the expression of SIRT1 protein is reduced accompanied by higher levels of acetylated p53 and p21 expression [76]. Resveratrol restores acetylated p53 and p 21 in the aorta and thus, improves endothelial dysfunction by down-regulating ICAM-1 expression and inhibiting leukocyte rolling [76], These data suggest a protective role for SIRT1 in the pathogenesis of diabetic vascular dysfunction.

In transgenic mice with heart-specific overexpression of SIRT1, beneficial effects are observed only in animals with a slight or moderate up-regulation of SIRT1, which is due to an increased catalase expression through FoxOdependent signaling. Furthermore, the heart-specific overexpression of SIRT1 retards aging of the heart and further protects the heart from paraquat-induced oxidative stress [4].

\section{Clinical perspective}

The proteins discussed in the present review represent different therapeutic targets for treatments of cardiovascular diseases, reducing cell damage or enhancing cell defenses.

The p66Shc protein is strongly linked to the generation of ROS. Genetic deletion of p66Shc prevents ROSmediated cell damage and by doing so reduces cellular apoptosis. Since the antioxidant treatments proposed to decreases cardiovascular events failed to reduce the risk of cardiovascular events in large long-term clinical trials [53, 90, 110], the inhibition of p66Shc seems to be a more attractive therapeutic option to reduce oxidative stress in humans.

SIRT1 exerts multiple protective effects. Physical training is reported to restore SIRT1 protein in both heart and adipose tissue of aged mice [34] supporting the beneficial effect of exercise training $[1,10,11,34,81,85,102]$. Resveratrol, one of the polyphenolic compounds in grapes and wine, is reported as a small molecule activator of SIRT1 [44, 49]. Resveratrol increases insulin secretion in pancreatic $\beta$ cells [68] and improves endothelial function in the aorta of diabetic mouse [76]. Besides, resveratrol reduces TNF- $\alpha$ induced tissue factor expression through inactivation of NFKB-mediated transcription [80] and thus, prevents cells' adhesiveness $[25,120]$. In addition, resveratrol delays cell senescence via PI3K-Akt pathway in endothelial progenitor cells [115].

\section{Summary and conclusions}

The p66Shc is a mitochondrial protein mediating oxidative stress. The inhibition of p66Shc reduces oxidative stress, suggesting that p66Shc is a promising target to reduce ROS-mediated cardiovascular disease. SIRT1 is a protein sensitive to energy change in metabolism and improves cell survival and functions by deacetylating regulatory proteins. Up-regulation of SIRT1 exhibits multiple beneficial effects on endothelial dysfunction especially in diabetes. It may be considered optimistic to assume that simply downregulating p66Shc, up-regulating SIRT1, or a combination of the two will effectively slow down aging in humans and

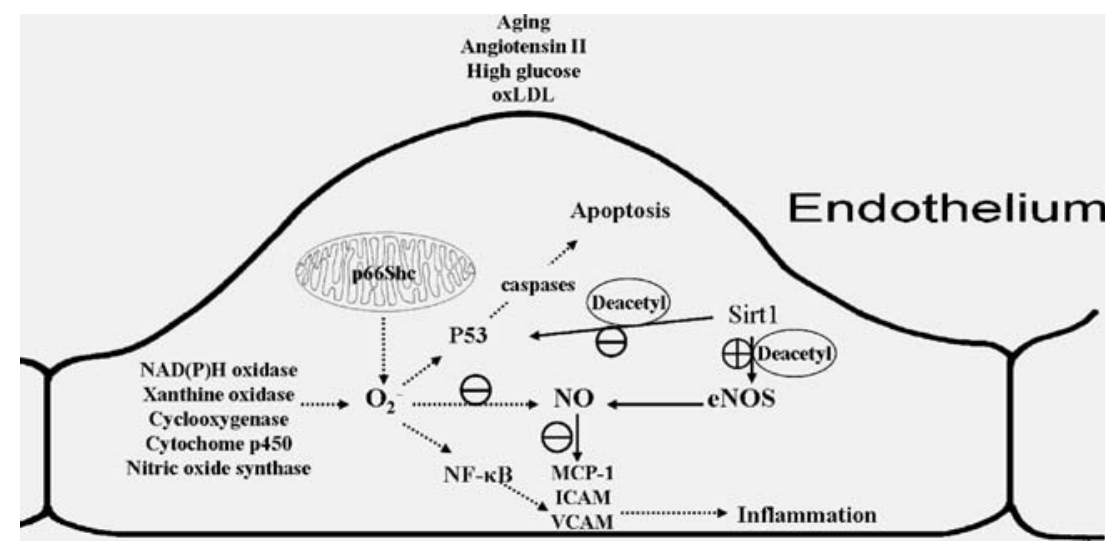

Fig. 4 Schematic representation of the endothelium and some of its key derived vasoactive substances. Different stress stimuli (e.g., glucose, oxLDL, and angiotensin II) and occurrence of aging enhance the production of $\mathrm{O}_{2}^{-}$and determine endothelial dysfunction. p66Shc is principally located in the mitochondria where it contributes to the production of $\mathrm{O}_{2}^{-}$, which scavenges $\mathrm{NO}$, and activates NF- $\mathrm{kB}$ and p53. Sirt1 deacetylates nitric oxide synthase, thus, restores NO availability. Sirt1 also deacetylates p53 and consequently, reduces cell apoptosis. The symbol $(\oplus)$ indicates activation while $(\ominus)$ indicates inhibition. oxLDL oxidized low density lipoprotein, NOS NO synthase, $N O$ nitric oxide, $M C P-1$ monocyte chemotactic protein-1, $I C A M$ intercellular adhesion molecule, VCAM vascular cells adhesion molecule, $N F-\kappa B$ nuclear factor-kappa B, $N A D P H$ nicotinamide adenine dinucleotide phosphate-oxidase, Deacetyl deacetylation 
shift the pathophysiological imbalance towards a normalized condition. Nevertheless, these recently discovered target proteins offer insights to better characterize underlying mechanisms of cardiovascular diseases and aging (Fig. 4).

\section{References}

1. Abete P, Ferrara N, Cacciatore F, Sagnelli E, Manzi M, Carnovale V, Calabrese C, de Santis D, Testa G, Longobardi G, Napoli C, Rengo F (2001) High level of physical activity preserves the cardioprotective effect of preinfarction angina in elderly patients. J Am Coll Cardiol 38:1357-1365. doi: Electronic Resource Number (111)

2. Adler A, Messina E, Sherman B, Wang Z, Huang H, Linke A, Hintze TH (2003) NAD(P)H oxidase-generated superoxide anion accounts for reduced control of myocardial $\mathrm{O} 2$ consumption by NO in old Fischer 344 rats. Am J Physiol Heart Circ Physiol 285:H1015-H1022. doi:Electronic Resource Number (44)

3. Aikawa M, Sugiyama S, Hill CC, Voglic SJ, Rabkin E, Fukumoto Y, Schoen FJ, Witztum JL, Libby P (2002) Lipid lowering reduces oxidative stress and endothelial cell activation in rabbit atheroma. Circulation 106:1390-1396. doi:Electronic Resource Number (53)

4. Alcendor RR, Gao S, Zhai P, Zablocki D, Holle E, Yu X, Tian B, Wagner T, Vatner SF, Sadoshima J (2007) Sirt1 regulates aging and resistance to oxidative stress in the heart. Circ Res 100:1512-1521. doi:Electronic Resource Number (106)

5. Baker CS, Hall RJ, Evans TJ, Pomerance A, Maclouf J, Creminon C, Yacoub MH, Polak JM (1999) Cyclooxygenase-2 is widely expressed in atherosclerotic lesions affecting native and transplanted human coronary arteries and colocalizes with inducible nitric oxide synthase and nitrotyrosine particularly in macrophages. Arterioscler Thromb Vasc Biol 19:646-655. doi: Electronic Resource Number (49)

6. Ballard VL, Edelberg JM (2007) Stem cells and the regeneration of the aging cardiovascular system. Circ Res 100:1116-1127. doi:Electronic Resource Number (2)

7. Barton M, Haudenschild CC, d'Uscio LV, Shaw S, Munter K, Luscher TF (1998) Endothelin ETA receptor blockade restores NO-mediated endothelial function and inhibits atherosclerosis in apolipoprotein E-deficient mice. Proc Natl Acad Sci U S A 95:14367-14372. doi:Electronic Resource Number (13)

8. Bath PM (1993) The effect of nitric oxide-donating vasodilators on monocyte chemotaxis and intracellular cGMP concentrations in vitro. Eur J Clin Pharmacol 45:53-58. doi:Electronic Resource Number (7)

9. Berniakovich I, Trinei M, Stendardo M, Migliaccio E, Minucci S, Bernardi P, Pelicci PG, Giorgio M (2008) p66Shc-generated oxidative signal promotes fat accumulation. J Biol Chem 283:34283-34293. doi:Electronic Resource Number (83)

10. Black MA, Green DJ, Cable NT (2008) Exercise prevents agerelated decline in nitric-oxide-mediated vasodilator function in cutaneous microvessels. J Physiol 586:3511-3524. doi:Electronic Resource Number (116)

11. Blumenthal JA, Sherwood A, Babyak MA, Watkins LL, Waugh R, Georgiades A, Bacon SL, Hayano J, Coleman RE, Hinderliter A (2005) Effects of exercise and stress management training on markers of cardiovascular risk in patients with ischemic heart disease: a randomized controlled trial. JAMA 293:1626-1634. doi:Electronic Resource Number (114)

12. Bonfini L, Migliaccio E, Pelicci G, Lanfrancone L, Pelicci PG (1996) Not all Shc's roads lead to Ras. Trends Biochem Sci 21:257-261. doi:Electronic Resource Number (75)
13. Bordone L, Motta MC, Picard F, Robinson A, Jhala US, Apfeld J, McDonagh T, Lemieux M, McBurney M, Szilvasi A, Easlon EJ, Lin SJ, Guarente L (2006) Sirt1 regulates insulin secretion by repressing UCP2 in pancreatic beta cells. PLoS Biol 4:e31. doi: Electronic Resource Number (99)

14. Boring L, Gosling J, Cleary M, Charo IF (1998) Decreased lesion formation in CCR2-/- mice reveals a role for chemokines in the initiation of atherosclerosis. Nature 394:894-897. doi: Electronic Resource Number (27)

15. Brunet A, Sweeney LB, Sturgill JF, Chua KF, Greer PL, Lin Y, Tran H, Ross SE, Mostoslavsky R, Cohen HY, Hu LS, Cheng HL, Jedrychowski MP, Gygi SP, Sinclair DA, Alt FW, Greenberg ME (2004) Stress-dependent regulation of FOXO transcription factors by the SIRT1 deacetylase. Science 303:2011-2015. doi: Electronic Resource Number (91)

16. Cacciapuoti F, Marfella R, Paolisso G (2009) Is the aging heart similar to the diabetic heart? Evaluation of LV function of the aging heart with Tissue Doppler Imaging. Aging Clin Exp Res 21:22-26. doi:Electronic Resource Number (37)

17. Cai H, Harrison DG (2000) Endothelial dysfunction in cardiovascular diseases: the role of oxidant stress. Circ Res 87:840 844. doi:Electronic Resource Number (33)

18. Camici GG, Cosentino F, Tanner FC, Luscher TF (2008) The role of p66Shc deletion in age-associated arterial dysfunction and disease states. J Appl Physiol 105:1628-1631. doi:Electronic Resource Number (79)

19. Camici GG, Schiavoni M, Francia P, Bachschmid M, MartinPadura I, Hersberger M, Tanner FC, Pelicci P, Volpe M, Anversa P, Luscher TF, Cosentino F (2007) Genetic deletion of p66(Shc) adaptor protein prevents hyperglycemia-induced endothelial dysfunction and oxidative stress. Proc Natl Acad Sci U S A 104:5217-5222. doi:Electronic Resource Number (58)

20. Cesselli D, Jakoniuk I, Barlucchi L, Beltrami AP, Hintze TH, Nadal-Ginard B, Kajstura J, Leri A, Anversa P (2001) Oxidative stress-mediated cardiac cell death is a major determinant of ventricular dysfunction and failure in dog dilated cardiomyopathy. Circ Res 89:279-286. doi:Electronic Resource Number (1)

21. Cohen HY, Miller C, Bitterman KJ, Wall NR, Hekking B, Kessler B, Howitz KT, Gorospe M, de Cabo R, Sinclair DA (2004) Calorie restriction promotes mammalian cell survival by inducing the SIRT1 deacetylase. Science 305:390-392. doi: Electronic Resource Number (95)

22. Collins T, Cybulsky MI (2001) NF-kappaB: pivotal mediator or innocent bystander in atherogenesis? J Clin Invest 107:255-264. doi:Electronic Resource Number (57)

23. Cosentino F, Francia P, Camici GG, Pelicci PG, Luscher TF (2007) Final common molecular pathways of aging and cardiovascular disease. Role of the p66Shc Protein. Arterioscler Thromb Vasc Biol Resource Number (78)

24. Cosentino F, Francia P, Camici GG, Pelicci PG, Luscher TF, Volpe M (2008) Final common molecular pathways of aging and cardiovascular disease: role of the p66Shc protein. Arterioscler Thromb Vasc Biol 28:622-628. doi:Electronic Resource Number (32)

25. Csiszar A, Smith K, Labinskyy N, Orosz Z, Rivera A, Ungvari Z (2006) Resveratrol attenuates TNF-alpha-induced activation of coronary arterial endothelial cells: role of NF-kappaB inhibition. Am J Physiol Heart Circ Physiol 291:H1694-H1699. doi: Electronic Resource Number (121)

26. Csiszar A, Ungvari Z, Edwards JG, Kaminski P, Wolin MS, Koller A, Kaley G (2002) Aging-induced phenotypic changes and oxidative stress impair coronary arteriolar function. Circ Res 90:1159-1166. doi:Electronic Resource Number (16)

27. Csiszar A, Wang M, Lakatta EG, Ungvari Z (2008) Inflammation and endothelial dysfunction during aging: role of NF- 
kappaB. J Appl Physiol 105:1333-1341. doi:Electronic Resource Number (24)

28. Cushing SD, Berliner JA, Valente AJ, Territo MC, Navab M, Parhami F, Gerrity R, Schwartz CJ, Fogelman AM (1990) Minimally modified low density lipoprotein induces monocyte chemotactic protein 1 in human endothelial cells and smooth muscle cells. Proc Natl Acad Sci U S A 87:5134-5138. doi: Electronic Resource Number (30)

29. Cybulsky MI, Iiyama K, Li H, Zhu S, Chen M, Iiyama M, Davis V, Gutierrez-Ramos JC, Connelly PW, Milstone DS (2001) A major role for VCAM-1, but not ICAM-1, in early atherosclerosis. J Clin Invest 107:1255-1262. doi:Electronic Resource Number (26)

30. de Belder A, Radomski M, Hancock V, Brown A, Moncada S, Martin J (1995) Megakaryocytes from patients with coronary atherosclerosis express the inducible nitric oxide synthase. Arterioscler Thromb Vasc Biol 15:637-641. doi:Electronic Resource Number (4)

31. De Vriese AS, Verbeuren TJ, Van de Voorde J, Lameire NH, Vanhoutte PM (2000) Endothelial dysfunction in diabetes. Br J Pharmacol 130:963-974. doi:Electronic Resource Number (35)

32. Di Stefano V, Cencioni C, Zaccagnini G, Magenta A, Capogrossi MC, Martelli F (2009) p66ShcA modulates oxidative stress and survival of endothelial progenitor cells in response to high glucose. Cardiovasc Res 82(3):421-429

33. Fernandez-Patron C, Radomski MW, Davidge ST (2000) Role of matrix metalloproteinase-2 in thrombin-induced vasorelaxation of rat mesenteric arteries. Am J Physiol Heart Circ Physiol 278: H1473-H1479. doi:Electronic Resource Number (6)

34. Ferrara N, Rinaldi B, Corbi G, Conti V, Stiuso P, Boccuti S, Rengo G, Rossi F, Filippelli A (2008) Exercise training promotes SIRT1 activity in aged rats. Rejuvenation Res 11:139-150. doi: Electronic Resource Number (110)

35. Finkel T, Holbrook NJ (2000) Oxidants, oxidative stress, and the biology of ageing. Nature 408:239-247. doi:Electronic Resource Number (42)

36. Fleming I, Mohamed A, Galle J, Turchanowa L, Brandes RP, Fisslthaler B, Busse R (2005) Oxidized low-density lipoprotein increases superoxide production by endothelial nitric oxide synthase by inhibiting PKCalpha. Cardiovasc Res 65:897-906. doi:Electronic Resource Number (54)

37. Francia P, delli Gatti C, Bachschmid M, Martin-Padura I, Savoia C, Migliaccio E, Pelicci PG, Schiavoni M, Luscher TF, Volpe M, Cosentino F (2004) Deletion of p66shc gene protects against age-related endothelial dysfunction. Circulation 110:2889-2895. doi:Electronic Resource Number (84)

38. Furchgott RF, Zawadzki JV (1980) The obligatory role of endothelial cells in the relaxation of arterial smooth muscle by acetylcholine. Nature 288:373-376. doi:Electronic Resource Number (5)

39. Gu L, Okada Y, Clinton SK, Gerard C, Sukhova GK, Libby P, Rollins BJ (1998) Absence of monocyte chemoattractant protein1 reduces atherosclerosis in low density lipoprotein receptordeficient mice. Mol Cell 2:275-281. doi:Electronic Resource Number (29)

40. Haberland ME, Fong D, Cheng L (1988) Malondialdehydealtered protein occurs in atheroma of Watanabe heritable hyperlipidemic rabbits. Science 241:215-218. doi:Electronic Resource Number (51)

41. Halliwell B (1996) Free radicals, proteins, and DNA: oxidative damage versus redox regulation. Biochem Soc Trans 24:10231027. doi:Electronic Resource Number (41)

42. Harman D (1956) Aging: a theory based on free radical and radiation chemistry. J Gerontol 11:298-300. doi:Electronic Resource Number (38)
43. Heymes C, Habib A, Yang D, Mathieu E, Marotte F, Samuel J, Boulanger CM (2000) Cyclo-oxygenase-1 and -2 contribution to endothelial dysfunction in ageing. Br J Pharmacol 131:804-810. doi:Electronic Resource Number (15)

44. Howitz KT, Bitterman KJ, Cohen HY, Lamming DW, Lavu S, Wood JG, Zipkin RE, Chung P, Kisielewski A, Zhang LL, Scherer B, Sinclair DA (2003) Small molecule activators of sirtuins extend Saccharomyces cerevisiae lifespan. Nature 425:191-196. doi:Electronic Resource Number (117)

45. Karasu C (1999) Increased activity of $\mathrm{H} 2 \mathrm{O} 2$ in aorta isolated from chronically streptozotocin-diabetic rats: effects of antioxidant enzymes and enzymes inhibitors. Free Radic Biol Med 27:16-27. doi:Electronic Resource Number (69)

46. Keegan A, Walbank H, Cotter MA, Cameron NE (1995) Chronic vitamin $\mathrm{E}$ treatment prevents defective endothelium-dependent relaxation in diabetic rat aorta. Diabetologia 38:1475-1478. doi: Electronic Resource Number (68)

47. Khan BV, Parthasarathy SS, Alexander RW, Medford RM (1995) Modified low density lipoprotein and its constituents augment cytokine-activated vascular cell adhesion molecule-1 gene expression in human vascular endothelial cells. J Clin Invest 95:1262-1270. doi:Electronic Resource Number (31)

48. Kitayama J, Yi C, Faraci FM, Heistad DD (2006) Modulation of dilator responses of cerebral arterioles by extracellular superoxide dismutase. Stroke 37:2802-2806. doi:Electronic Resource Number (45)

49. Knutson MD, Leeuwenburgh C (2008) Resveratrol and novel potent activators of SIRT1: effects on aging and age-related diseases. Nutr Rev 66:591-596. doi:Electronic Resource Number (118)

50. Kume N, Cybulsky MI, Gimbrone MA Jr (1992) Lysophosphatidylcholine, a component of atherogenic lipoproteins, induces mononuclear leukocyte adhesion molecules in cultured human, and rabbit arterial endothelial cells. J Clin Invest 90:1138-1144. doi:Electronic Resource Number (25)

51. Le S, Connors TJ, Maroney AC (2001) c-Jun N-terminal kinase specifically phosphorylates p66ShcA at serine 36 in response to ultraviolet irradiation. J Biol Chem 276:48332-48336. doi: Electronic Resource Number (76)

52. Li H, Cybulsky MI, Gimbrone MA Jr, Libby P (1993) An atherogenic diet rapidly induces VCAM-1, a cytokine-regulatable mononuclear leukocyte adhesion molecule, in rabbit aortic endothelium. Arterioscler Thromb 13:197-204. doi:Electronic Resource Number (28)

53. Liu S, Lee IM, Song Y, Van Denburgh M, Cook NR, Manson JE, Buring JE (2006) Vitamin E and risk of type 2 diabetes in the women's health study randomized controlled trial. Diabetes 55:2856-2862. doi:Electronic Resource Number (107)

54. Luo J, Nikolaev AY, Imai S, Chen D, Su F, Shiloh A, Guarente L, Gu W (2001) Negative control of p53 by Sir2alpha promotes cell survival under stress. Cell 107:137-148. doi:Electronic Resource Number (89)

55. Luscher TF, Tanner FC, Dohi Y (1992) Age, hypertension and hypercholesterolaemia alter endothelium-dependent vascular regulation. Pharmacol Toxicol 70:S32-S39. doi:Electronic Resource Number (34)

56. Luscher TF, Yang ZH, Diederich D, Buhler FR (1989) Endothelium-derived vasoactive substances: potential role in hypertension, atherosclerosis, and vascular occlusion. J Cardiovasc Pharmacol 14(Suppl 6):S63-S69. doi:Electronic Resource Number (9)

57. MacMillan-Crow LA, Crow JP, Thompson JA (1998) Peroxynitrite-mediated inactivation of manganese superoxide dismutase involves nitration and oxidation of critical tyrosine residues. Biochemistry 37:1613-1622. doi:Electronic Resource Number (21) 
58. Macmillan-Crow LA, Cruthirds DL (2001) Invited review: manganese superoxide dismutase in disease. Free Radic Res 34:325-336. doi:Electronic Resource Number (20)

59. Makimattila S, Virkamaki A, Groop PH, Cockcroft J, Utriainen T, Fagerudd J, Yki-Jarvinen H (1996) Chronic hyperglycemia impairs endothelial function and insulin sensitivity via different mechanisms in insulin-dependent diabetes mellitus. Circulation 94:1276-1282. doi:Electronic Resource Number (10)

60. Matsumoto T, Kakami M, Noguchi E, Kobayashi T, Kamata K (2007) Imbalance between endothelium-derived relaxing and contracting factors in mesenteric arteries from aged OLETF rats, a model of Type 2 diabetes. Am J Physiol Heart Circ Physiol 293:H1480-H1490. doi:Electronic Resource Number (62)

61. Matsumoto T, Noguchi E, Ishida K, Kobayashi T, Yamada N, Kamata K (2008) Metformin normalizes endothelial function by suppressing vasoconstrictor prostanoids in mesenteric arteries from OLETF rats, a model of type 2 diabetes. Am J Physiol Heart Circ Physiol 295:H1165-H1176. doi:Electronic Resource Number (63)

62. Matsumoto T, Yoshiyama S, Wakabayashi K, Kobayashi T, Kamata K (2004) Effects of chronic insulin on endothelial dysfunction of basilar arteries from established streptozotocindiabetic rats. Eur J Pharmacol 504:119-127. doi:Electronic Resource Number (60)

63. Mattagajasingh I, Kim CS, Naqvi A, Yamamori T, Hoffman TA, Jung SB, DeRicco J, Kasuno K, Irani K (2007) SIRT1 promotes endothelium-dependent vascular relaxation by activating endothelial nitric oxide synthase. Proc Natl Acad Sci U S A 104:14855-14860. doi:Electronic Resource Number (103)

64. Menini S, Amadio L, Oddi G, Ricci C, Pesce C, Pugliese F, Giorgio M, Migliaccio E, Pelicci P, Iacobini C, Pugliese G (2006) Deletion of p66Shc longevity gene protects against experimental diabetic glomerulopathy by preventing diabetesinduced oxidative stress. Diabetes 55:1642-1650. doi:Electronic Resource Number (86)

65. Menini S, Iacobini C, Ricci C, Oddi G, Pesce C, Pugliese F, Block K, Abboud HE, Giorgio M, Migliaccio E, Pelicci PG, Pugliese G (2007) Ablation of the gene encoding p66Shc protects mice against AGE-induced glomerulopathy by preventing oxidant-dependent tissue injury and further AGE accumulation. Diabetologia 50:1997-2007. doi:Electronic Resource Number (87)

66. Migliaccio E, Giorgio M, Mele S, Pelicci G, Reboldi P, Pandolfi PP, Lanfrancone L, Pelicci PG (1999) The p66shc adaptor protein controls oxidative stress response and life span in mammals. Nature 402:309-313. doi:Electronic Resource Number (74)

67. Migliaccio E, Mele S, Salcini AE, Pelicci G, Lai KM, SupertiFurga G, Pawson T, Di Fiore PP, Lanfrancone L, Pelicci PG (1997) Opposite effects of the p52shc/p46shc and p66shc splicing isoforms on the EGF receptor-MAP kinase-fos signalling pathway. Embo J 16:706-716. doi:Electronic Resource Number (82)

68. Milne JC, Lambert PD, Schenk S, Carney DP, Smith JJ, Gagne DJ, Jin L, Boss O, Perni RB, Vu CB, Bemis JE, Xie R, Disch JS, $\mathrm{Ng}$ PY, Nunes JJ, Lynch AV, Yang H, Galonek H, Israelian K, Choy W, Iffland A, Lavu S, Medvedik O, Sinclair DA, Olefsky JM, Jirousek MR, Elliott PJ, Westphal CH (2007) Small molecule activators of SIRT1 as therapeutics for the treatment of type 2 diabetes. Nature 450:712-716. doi:Electronic Resource Number (102)

69. Moncada S, Palmer RM, Higgs EA (1991) Nitric oxide: physiology, pathophysiology, and pharmacology. Pharmacol Rev 43:109-142. doi:Electronic Resource Number (8)

70. Moynihan KA, Grimm AA, Plueger MM, Bernal-Mizrachi E, Ford E, Cras-Meneur C, Permutt MA, Imai S (2005) Increased dosage of mammalian Sir2 in pancreatic beta cells enhances glucose-stimulated insulin secretion in mice. Cell Metab 2:105117. doi:Electronic Resource Number (100)

71. Napoli C, Martin-Padura I, de Nigris F, Giorgio M, Mansueto G, Somma P, Condorelli M, Sica G, De Rosa G, Pelicci P (2003) Deletion of the p66Shc longevity gene reduces systemic and tissue oxidative stress, vascular cell apoptosis, and early atherogenesis in mice fed a high-fat diet. Proc Natl Acad Sci U S A 100:2112-2116. doi:Electronic Resource Number (85)

72. Nemoto S, Combs CA, French S, Ahn BH, Fergusson MM, Balaban RS, Finkel T (2006) The mammalian longevityassociated gene product p66shc regulates mitochondrial metabolism. J Biol Chem 281:10555-10560. doi:Electronic Resource Number (77)

73. Nemoto S, Fergusson MM, Finkel T (2004) Nutrient availability regulates SIRT1 through a forkhead-dependent pathway. Science 306:2105-2108. doi:Electronic Resource Number (90)

74. Nisoli E, Tonello C, Cardile A, Cozzi V, Bracale R, Tedesco L, Falcone S, Valerio A, Cantoni O, Clementi E, Moncada S, Carruba MO (2005) Calorie restriction promotes mitochondrial biogenesis by inducing the expression of eNOS. Science 310:314-317. doi:Electronic Resource Number (98)

75. Nohl H, Kramer R (1980) Molecular basis of age-dependent changes in the activity of adenine nucleotide translocase. Mech Ageing Dev 14:137-144. doi:Electronic Resource Number (39)

76. Orimo M, Minamino T, Miyauchi H, Tateno K, Okada S, Moriya J, Komuro I (2009) Protective role of SIRT1 in diabetic vascular dysfunction. Arterioscler Thromb Vasc Biol 29:889-894. doi: Electronic Resource Number (101)

77. Ota H, Eto M, Kano MR, Ogawa S, Iijima K, Akishita M, Ouchi Y (2008) Cilostazol inhibits oxidative stress-induced premature senescence via upregulation of Sirt1 in human endothelial cells. Arterioscler Thromb Vasc Biol 28:1634-1639. doi:Electronic Resource Number (105)

78. Pagnin E, Fadini G, de Toni R, Tiengo A, Calo L, Avogaro A (2005) Diabetes induces p66shc gene expression in human peripheral blood mononuclear cells: relationship to oxidative stress. J Clin Endocrinol Metab 90:1130-1136. doi:Electronic Resource Number (81)

79. Pandolfi S, Bonafe M, Di Tella L, Tiberi L, Salvioli S, Monti D, Sorbi S, Franceschi C (2005) p66(shc) is highly expressed in fibroblasts from centenarians. Mech Ageing Dev 126:839-844. doi:Electronic Resource Number (80)

80. Pendurthi UR, Williams JT, Rao LV (1999) Resveratrol, a polyphenolic compound found in wine, inhibits tissue factor expression in vascular cells: a possible mechanism for the cardiovascular benefits associated with moderate consumption of wine. Arterioscler Thromb Vasc Biol 19:419-426. doi:Electronic Resource Number (119)

81. Radak Z, Naito H, Kaneko T, Tahara S, Nakamoto H, Takahashi R, Cardozo-Pelaez F, Goto S (2002) Exercise training decreases DNA damage and increases DNA repair and resistance against oxidative stress of proteins in aged rat skeletal muscle. Pflugers Arch 445:273-278. doi:Electronic Resource Number (112)

82. Radi R, Beckman JS, Bush KM, Freeman BA (1991) Peroxynitriteinduced membrane lipid peroxidation: the cytotoxic potential of superoxide and nitric oxide. Arch Biochem Biophys 288:481-487. doi:Electronic Resource Number (19)

83. Raij L (1991) Hypertension, endothelium, and cardiovascular risk factors. Am J Med 90:13S-18S. doi:Electronic Resource Number (11)

84. Richter C, Park JW, Ames BN (1988) Normal oxidative damage to mitochondrial and nuclear DNA is extensive. Proc Natl Acad Sci U S A 85:6465-6467. doi:Electronic Resource Number (40)

85. Rinaldi B, Corbi G, Boccuti S, Filippelli W, Rengo G, Leosco D, Rossi F, Filippelli A, Ferrara N (2006) Exercise training affects 
age-induced changes in SOD and heat shock protein expression in rat heart. Exp Gerontol 41:764-770. doi:Electronic Resource Number (115)

86. Rodgers JT, Lerin C, Haas W, Gygi SP, Spiegelman BM, Puigserver P (2005) Nutrient control of glucose homeostasis through a complex of PGC-1alpha and SIRT1. Nature 434:113118. doi:Electronic Resource Number (96)

87. Rodriguez-Manas L, Angulo J, Vallejo S, Peiro C, SanchezFerrer A, Cercas E, Lopez-Doriga P, Sanchez-Ferrer CF (2003) Early and intermediate Amadori glycosylation adducts, oxidative stress, and endothelial dysfunction in the streptozotocin-induced diabetic rats vasculature. Diabetologia 46:556-566. doi:Electronic Resource Number (70)

88. Romero MJ, Platt DH, Tawfik HE, Labazi M, El-Remessy AB, Bartoli M, Caldwell RB, Caldwell RW (2008) Diabetes-induced coronary vascular dysfunction involves increased arginase activity. Circ Res 102:95-102. doi:Electronic Resource Number (71)

89. Ryoo S, Lemmon CA, Soucy KG, Gupta G, White AR, Nyhan D, Shoukas A, Romer LH, Berkowitz DE (2006) Oxidized lowdensity lipoprotein-dependent endothelial arginase II activation contributes to impaired nitric oxide signaling. Circ Res 99:951960. doi:Electronic Resource Number (55)

90. Sesso HD, Buring JE, Christen WG, Kurth T, Belanger C, MacFadyen J, Bubes V, Manson JE, Glynn RJ, Gaziano JM (2008) Vitamins E and C in the prevention of cardiovascular disease in men: the Physicians' Health Study II randomized controlled trial. JAMA 300:2123-2133. doi:Electronic Resource Number (109)

91. Shi Y, Feletou M, Ku DD, Man RY, Vanhoutte PM (2007) The calcium ionophore A23187 induces endothelium-dependent contractions in femoral arteries from rats with streptozotocininduced diabetes. Br J Pharmacol 150:624-632. doi:Electronic Resource Number (14)

92. Shi Y, Man RY, Vanhoutte PM (2008) Two isoforms of cyclooxygenase contribute to augmented endotheliumdependent contractions in femoral arteries of 1-year-old rats. Acta Pharmacol Sin 29:185-192. doi:Electronic Resource Number (17)

93. Sinclair DA, Guarente L (1997) Extrachromosomal rDNA circles - a cause of aging in yeast. Cell 91:1033-1042. doi:Electronic Resource Number (97)

94. Sniderman AD, Furberg CD (2008) Age as a modifiable risk factor for cardiovascular disease. Lancet 371:1547-1549. doi: Electronic Resource Number (36)

95. Spitaler MM, Graier WF (2002) Vascular targets of redox signalling in diabetes mellitus. Diabetologia 45:476-494. doi: Electronic Resource Number (67)

96. Su J, Lucchesi PA, Gonzalez-Villalobos RA, Palen DI, Rezk BM, Suzuki Y, Boulares HA, Matrougui K (2008) Role of advanced glycation end products with oxidative stress in resistance artery dysfunction in type 2 diabetic mice. Arterioscler Thromb Vasc Biol 28:1432-1438. doi:Electronic Resource Number (59)

97. Szabo C, Salzman AL (1995) Endogenous peroxynitrite is involved in the inhibition of mitochondrial respiration in immuno-stimulated J774.2 macrophages. Biochem Biophys Res Commun 209:739-743. doi:Electronic Resource Number (22)

98. Szabo C, Zingarelli B, O'Connor M, Salzman AL (1996) DNA strand breakage, activation of poly (ADP-ribose) synthetase, and cellular energy depletion are involved in the cytotoxicity of macrophages and smooth muscle cells exposed to peroxynitrite. Proc Natl Acad Sci U S A 93:1753-1758. doi:Electronic Resource Number (18)

99. Taniguchi N, Takahashi M, Sakiyama H, Park YS, Asahi M, Misonou Y, Miyamoto Y (2005) A common pathway for intracellular reactive oxygen species production by glycoxidative and nitroxidative stress in vascular endothelial cells and smooth muscle cells. Ann N Y Acad Sci 1043:521-528. doi:Electronic Resource Number (72)

100. Tanner FC, Boulanger CM, Luscher TF (1993) Endotheliumderived nitric oxide, endothelin, and platelet vessel wall interaction: alterations in hypercholesterolemia and atherosclerosis. Semin Thromb Hemost 19:167-175. doi:Electronic Resource Number (50)

101. Tanner FC, Noll G, Boulanger CM, Luscher TF (1991) Oxidized low density lipoproteins inhibit relaxations of porcine coronary arteries. Role of scavenger receptor and endothelium-derived nitric oxide. Circulation 83:2012-2020. doi:Electronic Resource Number (56)

102. Taylor RS, Brown A, Ebrahim S, Jolliffe J, Noorani H, Rees K, Skidmore B, Stone JA, Thompson DR, Oldridge N (2004) Exercise-based rehabilitation for patients with coronary heart disease: systematic review and meta-analysis of randomized controlled trials. Am J Med 116:682-692. doi:Electronic Resource Number (113)

103. Tesfamariam B, Brown ML, Deykin D, Cohen RA (1990) Elevated glucose promotes generation of endothelium-derived vasoconstrictor prostanoids in rabbit aorta. J Clin Invest 85:929 932. doi:Electronic Resource Number (64)

104. van der Horst A, Tertoolen LG, de Vries-Smits LM, Frye RA, Medema RH, Burgering BM (2004) FOXO4 is acetylated upon peroxide stress and deacetylated by the longevity protein $\mathrm{hSir} 2$ (SIRT1). J Biol Chem 279:28873-28879. doi:Electronic Resource Number (92)

105. van der Loo B, Labugger R, Skepper JN, Bachschmid M, Kilo J, Powell JM, Palacios-Callender M, Erusalimsky JD, Quaschning T, Malinski T, Gygi D, Ullrich V, Luscher TF (2000) Enhanced peroxynitrite formation is associated with vascular aging. J Exp Med 192:1731-1744. doi:Electronic Resource Number (43)

106. Van der Vliet A, Smith D, O'Neill CA, Kaur H, Darley-Usmar V, Cross CE, Halliwell B (1994) Interactions of peroxynitrite with human plasma and its constituents: oxidative damage and antioxidant depletion. Biochem J 303(Pt 1):295-301. doi: Electronic Resource Number (23)

107. Vanhoutte PM (2009) Endothelial dysfunction: the first step toward coronary arteriosclerosis. Circ J 73:595-601. doi:Electronic Resource Number (4)

108. Vanhoutte PM, Tang EH (2008) Endothelium-dependent contractions: when a good guy turns bad! J Physiol 586:5295-5304. doi:Electronic Resource Number (12)

109. Vaziri H, Dessain SK, Ng Eaton E, Imai SI, Frye RA, Pandita TK, Guarente L, Weinberg RA (2001) hSIR2(SIRT1) functions as an NAD-dependent p53 deacetylase. Cell 107:149-159. doi: Electronic Resource Number (88)

110. Ward NC, Wu JH, Clarke MW, Puddey IB, Burke V, Croft KD, Hodgson JM (2007) The effect of vitamin E on blood pressure in individuals with type 2 diabetes: a randomized, double-blind, placebo-controlled trial. J Hypertens 25:227-234. doi:Electronic Resource Number (108)

111. Warnholtz A, Nickenig G, Schulz E, Macharzina R, Brasen JH, Skatchkov M, Heitzer T, Stasch JP, Griendling KK, Harrison DG, Bohm M, Meinertz T, Munzel T (1999) Increased NADHoxidase-mediated superoxide production in the early stages of atherosclerosis: evidence for involvement of the reninangiotensin system. Circulation 99:2027-2033. doi:Electronic Resource Number (48)

112. Wei Y, Whaley-Connell AT, Chen K, Habibi J, Uptergrove GM, Clark SE, Stump CS, Ferrario CM, Sowers JR (2007) NADPH oxidase contributes to vascular inflammation, insulin resistance, and remodeling in the transgenic (mRen2) rat. Hypertension 50:384-391. doi:Electronic Resource Number (61) 
113. Wilcox JN, Subramanian RR, Sundell CL, Tracey WR, Pollock JS, Harrison DG, Marsden PA (1997) Expression of multiple isoforms of nitric oxide synthase in normal and atherosclerotic vessels. Arterioscler Thromb Vasc Biol 17:2479-2488. doi: Electronic Resource Number (46)

114. Williams SB, Goldfine AB, Timimi FK, Ting HH, Roddy MA, Simonson DC, Creager MA (1998) Acute hyperglycemia attenuates endothelium-dependent vasodilation in humans in vivo. Circulation 97:1695-1701. doi:Electronic Resource Number (73)

115. Xia L, Wang XX, Hu XS, Guo XG, Shang YP, Chen HJ, Zeng CL, Zhang FR, Chen JZ (2008) Resveratrol reduces endothelial progenitor cells senescence through augmentation of telomerase activity by Akt-dependent mechanisms. $\mathrm{Br} \mathrm{J}$ Pharmacol 155:387-394. doi:Electronic Resource Number (122)

116. Yang Y, Hou H, Haller EM, Nicosia SV, Bai W (2005) Suppression of FOXO1 activity by FHL2 through SIRT1mediated deacetylation. EMBO J 24:1021-1032. doi:Electronic Resource Number (93)

117. Yeung F, Hoberg JE, Ramsey CS, Keller MD, Jones DR, Frye RA, Mayo MW (2004) Modulation of NF-kappaB-dependent transcription and cell survival by the SIRT1 deacetylase. EMBO J 23:2369-2380. doi:Electronic Resource Number (94)
118. Yla-Herttuala S, Palinski W, Rosenfeld ME, Parthasarathy S, Carew TE, Butler S, Witztum JL, Steinberg D (1989) Evidence for the presence of oxidatively modified low density lipoprotein in atherosclerotic lesions of rabbit and man. J Clin Invest 84:1086-1095. doi:Electronic Resource Number (52)

119. Yu T, Robotham JL, Yoon Y (2006) Increased production of reactive oxygen species in hyperglycemic conditions requires dynamic change of mitochondrial morphology. Proc Natl Acad Sci U S A 103:2653-2658. doi:Electronic Resource Number (65)

120. Zbikowska HM, Olas B, Wachowicz B, Krajewski T (1999) Response of blood platelets to resveratrol. Platelets 10:247-252. doi:Electronic Resource Number (120)

121. Zhang Q, Zhang RY, Zhang JS, Hu J, Yang ZK, Ni J, Fang YH, Zhang X, Shen WF (2006) One-year clinical outcomes of Chinese sirolimus-eluting stent in the treatment of unselected patients with coronary artery disease. Chin Med J (Engl) 119:165-168. doi:Electronic Resource Number (66)

122. Zhang QJ, Wang Z, Chen HZ, Zhou S, Zheng W, Liu G, Wei YS, Cai H, Liu DP, Liang CC (2008) Endothelium-specific overexpression of class III deacetylase SIRT1 decreases atherosclerosis in apolipoprotein E-deficient mice. Cardiovasc Res 80:191-199. doi:Electronic Resource Number (104) 